\title{
Performances of Nageswari duck of Bangladesh under intensive management condition
}

\author{
MSA Bhuiyan ${ }^{1 *}$, DS Mostary ${ }^{2}$, MS Ali ${ }^{2}$, MM Hussain $^{1}$ and AJM Ferdaus ${ }^{2}$ \\ Affiliation: ${ }^{1}$ Department of Animal Breeding and Genetics, Bangladesh Agricultural University, Mymensingh- \\ 2202, Bangladesh, '2Department of Poultry Science, Bangladesh Agricultural University, \\ Mymensingh-2202, Bangladesh,
}

\begin{abstract}
The present study was conducted to know the production and reproduction potentials, and egg quality characteristics of Nageswari duck under intensive management condition. Data were collected from a nucleus flock of Nageswari ducks that have been maintained from day old to 72 weeks of age at AI center, Bangladesh Agricultural University, Mymensingh, from May 2015 to October 2016. Irrespective of sex, the average live weight of ducklings at day old, $1^{\text {st }}, 3^{\text {rd }}, 5^{\text {th }}, 7^{\text {th }}$ and $9^{\text {th }}$ weeks of age were observed to be $38.85 \pm 1.40,99.06 \pm 2.93,373.29 \pm 8.73,650.31 \pm 11.26,867.74 \pm 11.79$ and $1076.11 \pm 16.34 \mathrm{~g}$, respectively. There was a steady increasing trend observed in live weights for both drakes and ducks from $17^{\text {th }}$ to 72 weeks of age. The average age of sexual maturity and weight were found $130 \pm 1.83$ days and $1400.84 \pm 12.68 \mathrm{~g}$ respectively. The average egg weight and annual egg production were $58.20 \pm 1.50 \mathrm{~g}$ and $204.23 \pm 14.19$ no's, respectively. Hen day egg production was found $55.67 \pm 2.74 \%$ while the peak production was observed at $26^{\text {th }}$ week of age. The estimated mean egg mass production ( $\mathrm{g} / \mathrm{b} /$ day), feed intake(g) during laying, feed conversion efficiency and performance

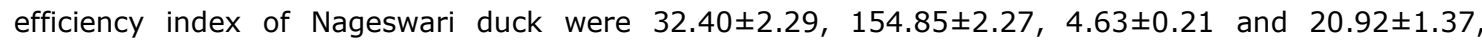
respectively in Nageswari duck. The external egg quality characteristics like shape index, egg breaking strength, shell thickness and membrane thickness were observed to be $74.59 \pm 0.61,2.00 \pm 0.03 \mathrm{~kg} / \mathrm{cm}^{2}$, $3.99 \pm 0.06 \mathrm{~mm}$ and $0.50 \pm 0.02 \mathrm{~mm}$ respectively whereas, internal quality attributes such as albumen index, yolk index, yolk color score and Haugh unit were 8.89 $\pm 0.29,34.36 \pm 0.61,8.42 \pm 0.28$ and $86.29 \pm 1.06$, respectively. In conclusion, the studied parameters of Nageswari duck provided some breed specific baseline information and year round actual production potentials of this genetic resource under intensive management condition that could be utilized for future conservation and breeding programs in Bangladesh.
\end{abstract}

Key words: growth, production, reproduction, egg quality, Nageswari duck

Bangladesh Animal Husbandry Association. All rights reserved.

Bang. J. Anim. Sci. 2017. 46 (3): 198-205

\section{Introduction}

Small-scale duck rearing has potential contribution to household economy, food security and improving the nutritional status of the rural people in Bangladesh. Duck stands second position in terms of total egg and poultry meat production in Bangladesh (Das et al., 2008). Total duck population in the country has been reported to be 47.25 million (BER, 2013), of which 95 percent are of indigenous or nondescript type scattered throughout the country (Hoque and Sultana, 2003). Besides, Khaki Campbell, Indian runner and Jinding, and their crosses are being reared by limited farmers in some duck populated areas due to have better production. Indigenous ducks are preferred by the farmers under traditional scavenging system due to their high adaptability to farming conditions, better foraging ability, long productive life and less affected by diseases (Pervin et al., 2013; Morduzzaman et al., 2015). Traditionally, farmers used to maintain a small duck flock along with their chickens throughout the country. However, large-scale duck farming ranging from around one hundred to thousands is found particularly in the north-eastern and coastal regions of the country where the land ecology, agro-climatic condition and natural feed resources largely influence on duck population demography (Khanum et al., 2005). In addition, the abundant low laying river basin areas, marshy lands, beels, haors, and cannels of the country make good option for profitable duck farming by rural householders (Rahman et al., 2009).

Nageswari is an egg type indigenous duck breed which sparsely distributed in the Barak valley

*Corresponding author: bhuiyansa@yahoo.com 
basin areas of India and Bangladesh. They are also locally called "Nagi" or "white breasted Nagi" due to their head-high snake like posture (snake deity) with white stripe in the neck extending up to breast (Islam et al., 2002; Zaman et al., 2005). The bluish tinge egg and completely black or penciled black plumage color except breast region are the characteristic features of this breed. The original homeland of this breed is believed to be the erstwhile Sylhet district of Bangladesh (Zaman et al., 2005). The Barak Valley basin is surrounded by hills and rivers with abundance of surface water and agricultural fields. Duck farming has traditionally become popular among the people of these regions. Over the years, the rampant crossbreeding with exotic breeds leads to gradual disappearance of pure Nageswari duck in their homeland and there is a risk of extinction this germplasm in near future. Now it is hard to find them in their place of origin (personal communication). However, better concentration of this breed was found in the duck potential areas of Mymensingh, Kishoreganj and Netrokona districts (Morduzzaman et al., 2015).

Previous studies reported quite large variation in the productive and reproductive performances of Nageswari duck with its, management and data collection perspective. Relatively lower egg production per year (120 to 150 numbers) of Nageswari ducks under scavenging conditions in Assam (Islam et al., 2002; Sharma et al., 2003 and Zaman et al., 2005) was recorded compared to Valavan et al. (2009) who found more than 200 eggs per year under intensive management condition. Khatun et al. (2012) reported egg production rate of Nageswari duck up to 52 week of age was $55.40 \pm 2.36 \%$ under farmer's condition of Bangladesh. On the contrary, indigenous ducks of Bangladesh are low productive, lay only 60-80 eggs per year (Rahman et al.,2009; Pervin et al., 2013). However, information is scanty about their actual capabilities in terms of production, reproduction and egg quality attributes under proper feeding and management condition. Establishment of database on production and fitness traits are the first and foremost requisites before taking any conservation and breeding scheme for a breed or species. Therefore, the study was designed to know the year round production and reproduction potentials as well as egg quality attributes of Nageswari duck under intensive management condition.

\section{Materials and Methods}

\section{Establishment of a nucleus flock}

This study was conducted at Artificial Insemination (AI) Center, Bangladesh Agricultural University, Mymensingh from May 2015 to October 2016. A total of 122 day old ducklings was collected from selected duck farms in Tarail Upazila of Kishoreganj district mainly based on phenotypic features of breeding flocks. Ducklings were brooded up to 3 weeks of age and then, growing ducklings were reared on floor. Individual selection was performed twice at the age of $9^{\text {th }}$ and $16^{\text {th }}$ weeks based on their growth performance and phenotypic features conform to breed characteristics. Details on morphology and morphometric features of Nageswari duck were described in the previous study by Morduzzaman et al. (2015). Finally, forty Nageswari ducks (34 female birds and 6 male birds) was kept as nucleus flock and were individually tagged using leg band.

Table 1. Nutrient composition of ration supplied to experimental Nageswari duck*

\begin{tabular}{|l|c|c|c|c|}
\hline Nutrients & $\begin{array}{c}\text { Starter } \\
(\mathbf{0 - 4} \text { weeks })\end{array}$ & $\begin{array}{c}\text { Grower } \\
\mathbf{( 5 - 1 7} \text { weeks) }\end{array}$ & $\begin{array}{c}\text { Pre-laying } \\
\mathbf{( 1 8 - 1 9} \text { weeks) }\end{array}$ & $\begin{array}{c}\text { Laying } \\
\text { (20-72 weeks) }\end{array}$ \\
\hline ME(Kcal/kg) & $2700-2800$ & $2500-2600$ & $2600-2700$ & $2600-2700$ \\
\hline CP $(\%)$ & $20-21$ & $14-15$ & $16-17$ & $18-19$ \\
\hline Lysine & 0.80 & 0.70 & 0.78 & 0.88 \\
\hline Methionine & 0.40 & 0.29 & 0.32 & 0.36 \\
\hline Met.+ Cysteine & 0.58 & 0.42 & 0.62 & 0.70 \\
\hline Calcium & 1.10 & 1.00 & 2.75 & 3.00 \\
\hline Avai. phosphorus & 0.50 & 0.50 & 0.48 & 0.52 \\
\hline
\end{tabular}

*Vitamin- mineral premix was added at a rate of $0.5 \mathrm{~kg}$ per $100 \mathrm{~kg}$ feed. 


\section{Performance of Nageswari duck of Bangladesh}

\section{Feeding and management practices}

Hand mixed mash feed was provided twice daily (morning and evening) throughout the experiment periods while commercial compound starter feed was provided only for first 4 weeks. Feeder and waterer were cleaned daily prior to feed supply in the morning and clean water was supplied ad libitum twice daily. The nutrient compositions (Table 1 ) of the supplied rations were given as per requirements of duck ration (NRC, 1994).Ducks were vaccinated against duck plague and duck cholera as per manufacturer's recommendation. Photoperiod was adjusted to 16 hours/day by providing artificial light during the laying period. During day time, ducks were allowed to stay 6-7 hours in a small pond nearby the shed. Sufficient egg laying boxes were given and egg laying place (laying box or floor) was recorded to know the laying behavior of duck. Strict bio-security measures and hygienic control were maintained for obtaining healthy environments of ducks.

\section{External and internal egg quality characteristics}

A total of 24 fresh eggs were collected from the flock at the age of 35 weeks to investigate external and internal egg quality attributes according to the methods outlined by Chowdhury (1987) and Ferdaus et al. (2015). The egg quality characteristics included egg length, egg width, shape index, egg breaking strength, egg surface area, egg volume, egg density, shell thickness and membrane thickness, albumen index, yolk index, yolk color score, yolk weight (\%), albumin weight (\%) and Haugh unit (HU).

\section{Record keeping and data analysis}

Data on live weight and feed consumption were recorded weekly in the flock up to 20 weeks of age and then, were recorded monthly interval up to 72 weeks of age. Egg production and egg laying behavior were recorded regularly while egg weight data were recorded fortnightly. Besides, disease incidence and mortality rate was also registered. Based on the recorded information, several production efficiency indicators like henday egg production (\%), annual egg production/duck, egg mass production (g/bird/day), feed conversion efficiency and performance efficiency index were estimated. Descriptive statistics such as mean, standard error, frequency, percentage and graphs were performed to represent the data using Microsoft Excel 2013.

\section{Results and Discussion}

\section{Body weight}

Growth performances of straight run Nageswari ducklings under intensive management condition up to $9^{\text {th }}$ week of age are presented in Table 2 . The average live weights of ducklings at day old, 1st, 3rd, 4th, 5th, 6th, 7th, $8^{\text {th }}$ and 9th week of age were observed to be $38.85 \pm 1.40,99.06 \pm$ $2.93,373.29 \pm 8.73,457.09 \pm 15.89,650.31 \pm$ $11.26,884.9 \pm 22.36,867.74 \pm 11.79,933.48 \pm$ 19.65 and $1076.11 \pm 16.34 \mathrm{~g}$ respectively. The values obtained by Morduzzaman et al. (2015) were almost similar to the present observation. On the other hand, Islam et al. (2014) found the average weight $(36.24 \pm 2.90 \mathrm{~g})$ of day old Nageswari duckling which was little lower than the present findings. However, Khatun et al. (2012) reported $8^{\text {th }}$ week live weight of Nageswari duckling was observed to be 1090.06 $\pm 122.84 \mathrm{~g}$ at farmer's level with supplementation which is little higher than the present study.

On the contrary, Sharma et al.(2003) and Zaman et al.(2007) reported quite lower live weight of ducklings up to 8 weeks of age under farmer's condition. The difference between present and previous studies might be due to availability of feed, nutrient contents in the feed, investigated sample size and management practices. After $9^{\text {th }}$ week, live weight of male and female ducks were recorded separately up to 72 weeks of age and is presented in Figure 1. There was a steady increasing trend observed in live weights after $17^{\text {th }}$ week in both sexes. The average body weight of Nageswari male and female duck at 23 weeks of age was 1.43 and $1.42 \mathrm{~kg}$ which are similar with the previous observation of Islam et al.(2002). However, Zaman et al.(2007) reported adult body weight of Nageswari duck to be varied from 1.60 to $1.66 \mathrm{~kg}$ in males and 1.45 to 1.50 $\mathrm{kg}$ in females that was a bit higher than the present investigation.

\section{Productive and reproductive performances}

The productive and reproductive performances of Nageswari ducks under intensive management condition are presented in Table 3. In this study, the average age and weight at first egg (AFE) of Nageswari duck were found $130 \pm 1.83$ days and $1400.84 \pm 12.68 \mathrm{~g}$, respectively. 
Bhuiyan et al. (2017) Bang. J. Anim. Sci. 46 (3):198-205

Table 2. Growth performances of Nageswari ducklings up to $9^{\text {th }}$ week of age

\begin{tabular}{ccccc}
\hline \multirow{2}{*}{ Week } & $\begin{array}{c}\text { Number of } \\
\text { observation }\end{array}$ & Min & Max & Mean \pm SE \\
\cline { 3 - 5 } Day old & 38 & 24 & 56 & $38.85 \pm 1.40$ \\
1st & 52 & 47 & 138 & $99.06 \pm 2.93$ \\
3rd & 37 & 291 & 477 & $373.29 \pm 8.73$ \\
4th & 32 & 250 & 588 & $457.09 \pm 15.89$ \\
5th & 57 & 385 & 904 & $650.31 \pm 11.26$ \\
6th & 42 & 620 & 1112 & $884.90 \pm 22.36$ \\
7th & 57 & 602 & 1136 & $867.74 \pm 11.79$ \\
8th & 36 & 620 & 1090 & $933.48 \pm 19.65$ \\
9th & 37 & 791 & 1280 & $1076.11 \pm 16.34$ \\
\hline
\end{tabular}

Table 3. Productive and reproductive performances of Nageswari ducks up to 72 weeks of age

\begin{tabular}{|c|c|}
\hline Parameter & Mean \pm SE \\
\hline Age at first egg (day) & $130 \pm 1.83$ \\
\hline Weight at sexual maturity $(\mathrm{g})$ & $1400.84 \pm 12.68$ \\
\hline Hen day egg production (\%) & $55.67 \pm 2.74$ \\
\hline Annual egg production/duck & $204.23 \pm 14.19$ \\
\hline Average egg weight (g) & $58.20 \pm 1.50$ \\
\hline Egg mass production (g/bird/day) & $32.40 \pm 2.29$ \\
\hline Feed intake during laying (g/day) & $154.85 \pm 2.27$ \\
\hline Feed conversion efficiency & $4.63 \pm 0.21$ \\
\hline Performance efficiency index & $20.92 \pm 1.37$ \\
\hline $\begin{array}{l}\text { Khatun et al. (2012) reported about a half month } \\
\text { higher age at first egg ( } 147 \pm 3.64 \text { day) and } \\
\text { almost similar weight ( } 1455 \pm 41.23 \mathrm{~g} \text { ) at the } \\
\text { time of sexual maturity compared to the present } \\
\text { investigation under farmer's condition. } \\
\text { Morduzzaman et al. ( } 2015) \text { reported that average } \\
\text { age at first egg of Nageswari breed was } 162.67 \pm \\
5.90 \text { days under farm condition and } 174.29 \pm \\
1.16 \text { days under farmer's level. Both } \\
\text { investigations were higher than the present } \\
\text { findings. Sharma et al.(2003) found average age } \\
\text { at first egg to be } 181.94 \pm 1.57 \text { days whereas, } \\
\text { Zaman et al.(2005) and Islam et al.(2002) } \\
\text { reported that average age at first egg (AFE) of } \\
\text { Nageswari duck was } 188 \text { days with a range of } \\
174-198 \text { days and } 180-195 \text { days respectively. It } \\
\text { revealed that significantly earlier age at first egg }\end{array}$ & $\begin{array}{l}\text { was observed compared to other previous } \\
\text { investigations. It might be due to the supply of } \\
\text { sufficient amount of balanced feed and better } \\
\text { management particularly in the early stage could } \\
\text { accelerate growth performance and attain earlier } \\
\text { puberty in duck. } \\
\text { Hen day egg production } \\
\text { Figure } 2 \text { represents the hen-day egg production } \\
\text { of Nageswari duck under intensive management } \\
\text { practices. Hen day egg production was found } \\
55.67 \pm 2.74 \% \text { and average annual egg production } \\
\text { was } 204.23 \pm 14.19 \text {. This result is in accordance } \\
\text { with the findings of Valavan et al. ( } 2009 \text { ) who } \\
\text { reported average annual egg production to be } \\
200-220 \text { in Nageswari duck under intensive } \\
\text { management system. Khatun et al. ( } 2012 \text { ) found } \\
55.40 \pm 2.36 \% \text { egg production rate up to } 52\end{array}$ \\
\hline
\end{tabular}


weeks of age in Nageswari duck which is relatively lower than the present study (60.19 \pm 3.63 ) considering the same age of hen day egg production. Study also revealed from Morduzzaman et al. (2015) that total number of eggs laid per year ranged between 146 and 201 with an average egg production of $173.63 \pm 3.39$ eggs and is relatively lower than present observation. This difference might be due to imbalanced ration formulation, insufficient feed supply and also poor management practices.

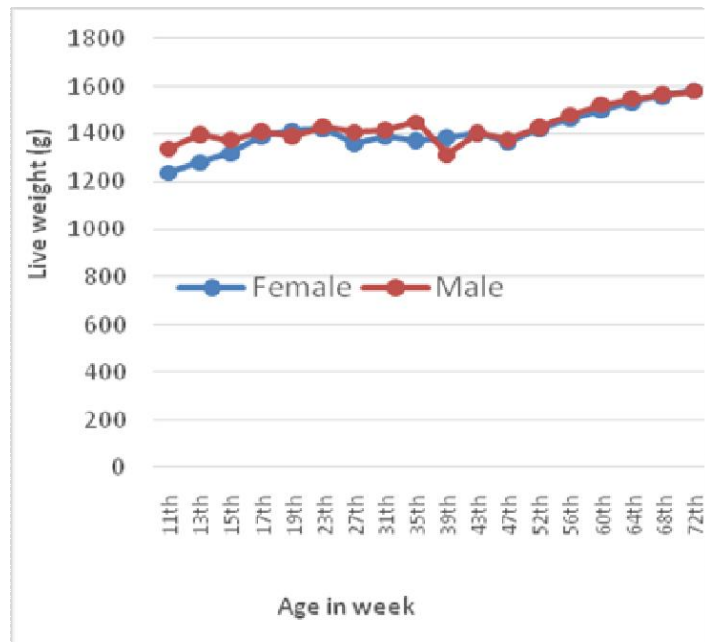

Figure 1. Growth performances of Nageswari male and female duck up to 72 weeks of age

However, in the present study, ducks reached their peak production at $26^{\text {th }}$ week of age. Considering annual egg production, there were 5 laying peaks depicted by their highest egg production concentrating at 26, 36, 44, 54 and $70^{\text {th }}$ week of age and the tenure of each laying cycle persisted in and around 45 days (Figure 2). On the other hand, Zaman et al. (2005) and Mahanta et al. (1998) reported higher egg laying cycles (6-7 cycles) each consisted of around 28 days in Nageswari and Chara-chamballi ducks. It is suggested that laying cycle could be extended through providing required amount balanced feed, better management and selection of good layers.

\section{Egg weight and laying behavior}

The average egg weight was estimated as being $58.20 \pm 1.50 \mathrm{~g}$ in the present study (Table 3 ). This result is in accordance with the findings of
Khatun et al. (2012) who reported average egg weight to be $57.22 \pm 1.89 \mathrm{~g}$ in Nageswari ducks. In addition, almost similar egg weight (56-60g) was reported both in Bangladeshi indigenous and Indian Nageswari duck (Das and Hoq, 2000; Islam et al., 2002; Rahman et al., 2009). Higher egg weight also reported by Sharma et al.(2002) in Nageswari duck (62.45g) and Mahanta et al.(2009) in Chara-chamballi duck (71.6g) of Assam. Egg weight increased linearly with age despite the difference was insignificant from 26 to 72 weeks of age (Figure 3). Relatively smaller eggs might be a breed characteristic features of Nageswari ducks as revealed by the findings of present and earlier studies. Unlike to chicken, we found only $40 \%$ ducks lay eggs in the laying box even though sufficient laying nests were provided in the shed.

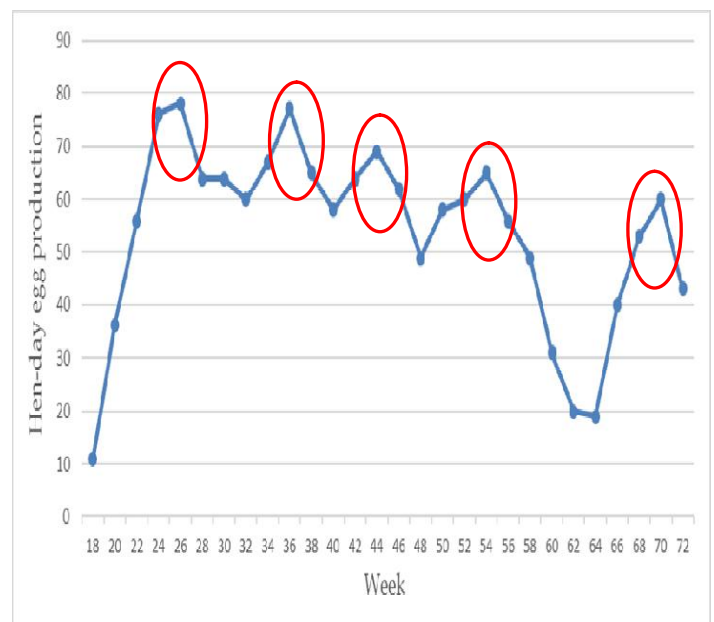

Figure 2. Year round hen-day egg production of Nageswari duck under intensive management condition. Year round egg laying peaks are presented with red round circles.

\section{Feed consumption, feed conversion efficiency and mortality}

The average feed consumption and feed conversion efficiency during laying ( $\mathrm{g} / \mathrm{b} /$ day) period was $154.85 \pm 2.27 \mathrm{~g}$ and $4.63 \pm 0.21$ respectively in Nageswari duck. The present study shown that egg mass production ( $\mathrm{g} / \mathrm{b} /$ day) was $32.40 \pm 2.29$ and performance efficiency index was $20.92 \pm 1.37$ (Table 3). However, lack of information on feed consumption and conversion efficiency particularly in ducks limits the scope to compare with other studies. The mortality rate of the present study was found 


\section{Performance of Nageswari duck of Bangladesh}

$6.0,4.67$ and $3.0 \%$ during the periods of day old to 8 weeks, 9 to 19 weeks and 20 to 72 weeks of age respectively. The mortality rates of the present study are within the range as reported by Khatun et al. (2012).

Table 4. External and internal egg quality characteristics of Nageswari duck ${ }^{1}$

\begin{tabular}{lr}
\hline Parameter & Mean \pm SE \\
\hline Egg weight $(\mathrm{g})$ & $55.56 \pm 0.87$ \\
Egg length $(\mathrm{mm})$ & $56.04 \pm 0.52$ \\
Egg width $(\mathrm{mm})$ & $41.74 \pm 0.19$ \\
Shape index & $74.59 \pm 0.61$ \\
Egg breaking strength & $2.03 \pm 0.03$ \\
(kg/ cm $\left.{ }^{2}\right)$ & \\
Egg surface area $\left(\mathrm{cm}^{2}\right)$ & $67.19 \pm 0.67$ \\
Egg volume $\left(\mathrm{cm}^{3}\right)$ & $51.86 \pm 0.77$ \\
Egg density $\left(\mathrm{g} / \mathrm{cm}^{3}\right)$ & $1.063 \pm 0.00$ \\
Shell thickness $\left(\mathrm{mm}^{2}\right)$ & $0.39 \pm 0.06$ \\
Membrane thickness & $0.50 \pm 0.02$ \\
(mm) & $8.89 \pm 0.29$ \\
Albumen index & $34.36 \pm 0.61$ \\
Yolk index & $8.42 \pm 0.28$ \\
Yolk color score & $32.37 \pm 0.38$ \\
Yolk weight $(\%)$ & $51.73 \pm 0.68$ \\
Albumin weight $(\%)$ & $86.29 \pm 1.06$ \\
Haugh unit $(\mathrm{HU})$ & \\
\hline
\end{tabular}

${ }^{1}$ fresh eggs were investigated from the flock at the age of 35 weeks for internal and external egg quality characteristic

On the other hand, Morduzzaman et al.(2015) reported that mortality rate was $2.0 \%$ up to 2 months and $1.5 \%$ from 2 months to adult stage in Nageswari duck which is lower than the present findings. In other studies, Islam et al.(2002) and Sharma et al.(2003) reported much higher mortality (below 10\%) of adult Nageswari ducks in Assam. Actually, mortality rate is primarily depending on immune status and management system of the flock and therefore, difficult to compare across flocks under different management practices.

\section{External and internal egg quality}

The mean external and internal egg quality characteristics are shown in Table 4.The external egg quality characteristics like egg weight, egg length, egg width, shape index, egg breaking strength, egg surface area, egg volume, egg density, shell thickness and membrane thickness we rerecorded to be55.56 $\pm 0.87 \mathrm{~g}, 56.04 \pm 0.52$ $\mathrm{mm}, 41.74 \pm 0.19 \mathrm{~mm}, 74.59 \pm 0.61,2.00 \pm$ $0.03 \mathrm{~kg} / \mathrm{cm}^{2}, 67.19 \pm 0.67 \mathrm{~cm}^{2}, 51.86 \pm 0.77$ $\mathrm{cm}^{3}, 1.063 \pm 0.00 \mathrm{~cm}^{3}, 3.99 \pm 0.06 \mathrm{~mm}$ and $0.50 \pm 0.02 \mathrm{~mm}$ respectively. Similarly, internal egg quality characteristics shown that the albumen index, yolk index, yolk color score, yolk weight(\%), albumin weight (\%) and Haugh unit (HU) were $8.89 \pm 0.29,34.36 \pm 0.61,8.42 \pm$ $0.28,32.37 \pm 0.38,51.73 \pm 0.68$ and $86.29 \pm$ 1.06 respectively. Above mentioned egg quality characteristics are very much close to the previous findings of Khatun et al. (2012) and Palanivel et al. (2011). On the other hand, present results are also in agreement with the findings as reported by Sharma et al. (2002).

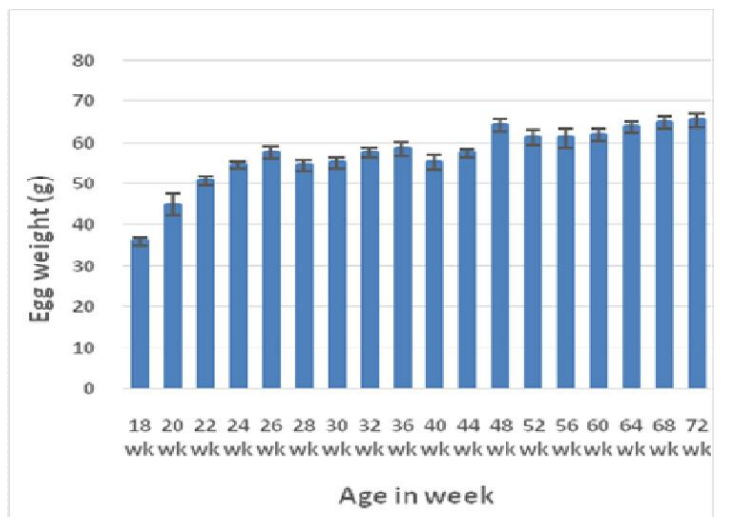

Figure 3. Relationship between age and egg weight of Nageswari duck

\section{Acknowledgements}

This study was conducted by the financial support of Bangladesh Agricultural University Research System (BAURES, Grant No. 2014/67/BAU).

\section{Conclusion}

Above all, this study reported growth performances, year round actual production and reproduction potentialities of Nageswari duck from the recorded data of a nucleus flock that maintained under intensive management condition. Egg production potentialities were found almost 2.5 times higher than available indigenous ducks. Therefore, this finding revealed that Nageswari duck as promising indigenous duck genetic resource that that need to be conserved immediately for further genetic erosion. 


\section{References}

BER (2013). Bangladesh Economic Review. Ministry of Finance, Government of the People's Republic of Bangladesh, Dhaka. pp.92-93.

Chowdhury SD (1988). Method of partitioning eggs components. Bangladesh Journal of Animal Science 17:93-97.

Das GB and ME Hoq (2000). Performance of Khaki Campbell, Jinding and Khaki Campbell $\times$ Indigenous ducks in integrated fish-cum-duck farming system. Bangladesh Journal of Animal Science 29:111-117.

Das SC, SD Chowdhury, MA Khatun, M Nishibori, $\mathrm{N}$ Isobe and Y Yoshimura (2008). Poultry production profile and expected future projection in Bangladesh. World's Poultry Science Journal 64:99-116.

Ferdaus AJM, MSA Bhuiyan, AKFH Bhuiyan, MS Ali, BM Hassin and MAR Howlider (2015). Reproductive potentials, meat yield and egg quality characteristics of indigenous dwarf chicken of Bangladesh. Asian Journal of Medical and Biological Research 1:416423.

Huque QME and N Sultana (2003). Organic duck farming in Bangladesh and entrepreneurship development. Proceedings of $3^{\text {rd }}$ International Poultry Show and Seminar, Organized by World's Poultry Science Association, Bangladesh Branch pp. 279-287.

Islam MS, $\mathrm{H}$ Khatun, MN Islam, S Faruque and MSK Sarker (2014). Study on the productive and reproductive performances of BLRI-1 and BLRI-2 ducks in Bangladesh. The Agriculturists 12:10-14.

Islam R, JD Mahanta, N Barua and G Zaman (2002). Duck farming in North-Eastern India (Assam). World's Poultry Science Journal 8: 567-572.

Khanum J, A Chwalibog and KS Huque (2005). Study on rural duck production systems in selected areas of Bangladesh. Livestock Research for Rural Development, 17 (10) http://www.Irrd.org/Irrd17/10/khan17113. $\mathrm{htm}$
Khatun $\mathrm{H}$, MN Islam, AA Bhuyan, MN Hasan and MS Islam (2012). Performance of BLRI developed native duck under farmer's condition with supplementary feeding. Bangladesh Journal of Livestock Research 19: 18-23.

Mahanta JD, J Raj, D Sapcota and A Jalaludeen (2009). Certain performance traits of Chara-chamballi ducks of Kelara under range condition in Assam. IV World Waterfowl Conference organized by Kerala Agricultural University, Thrissur, India.

Mahanta JD, A Ramakrishnan and A Jalaludeen (1998). Egg production performance of two indigenous types of ducks in Kerala. Journal of Veterinary Animal Science 29: 30-35.

Morduzzaman M, AKFH Bhuiyan, M Rana, MR Islam and MSA Bhuiyan (2015). Phenotypic characterization and production potentials of Nageswari duck in Bangladesh. Bangladesh Journal of Animal Science 44: 92-99.

NRC (1994). Nutrient Requirements of Poultry $\left(9^{\text {th }} \mathrm{Edn}\right)$, Washington, DC, The National Academies Press. https://doi.org/10.17226/2114.

Palanivel P and S Harikrishnan (2011). A glance at internal and external qualities of Kuttanad, White Pekin and commercial duck eggs. College of Veterinary and Animal Sciences, Mannuthy, Kerala.

Pervin W, SD Chowdhury, MA Ali, JU Khan and SK Raha (2013). Growth performance of indigenous (desi) ducklings receiving diets of varying nutrient concentrations. Proceedings of the 8th International Poultry Show and Seminar, WPSA-BB, 28 February-02 March, Dhaka, Bangladesh, pp. 45-50.

Rahman MM, MJ Khan, SD Chowdhury and MA Akbar (2009). Duck rearing system in southern coastal districts of Bangladesh. Bangladesh Journal Animal Science 38: 132-141.

Sharma SS, G Zaman, RN Goswami and JD Mahanta (2003). Certain performance traits of Nageswari ducks of Assam under range condition. Indian Journal of Animal Science 73:831-832. 
Sharma SS, G Zaman, RN Goswami, TC Roy and JD Mahanta (2002). Physical characteristics of Nageswari duck eggs of Assam. Indian Journal of Animal Science 72:77-1178.

Valavan SE, TS Kumar, N Vengadabady, K Mani, SC Edwin and A Bharathidhasan (2009). Duck production system in Tamin Nadu. Proceeding of the 4th world waterfowl conference 11-13 November, organized by Kerala Agricultural University, Thrissur, India 291-298.

Zaman G, RN Goswami, A Aziz, N Nahardeka and JD Mahanta (2007). Studies on body weight and shank length of Nageswari duck of Assam. Indian Journal Poultry Science 42: $79-80$.

Zaman G, RN Goswami, A Aziz, N Nahardeka, TC Roy and JD Mahanta (2005). Farming system of Nageswari ducks in NorthEastern India (Assam). World's Poultry Science Journal 61: 687-693. 